\title{
Rootstock Affect Bloom Date and Fruit Maturation of 'Redhaven' Peach
}

\author{
T.G. Beckman ${ }^{1}$ and W.R. Okie ${ }^{1}$ \\ Southeastern Fruit and Tree Nut Research Laboratory, Agricultural Research Service, U.S. \\ Department of Agriculture, P. O. Box 87 Byron, GA 31008
}

S.C. Meyers ${ }^{2}$

Department of Horticulture, University of Georgia, Athens, GA 30602

Additional index words. flowering, maturity, Prunus penica

\begin{abstract}
Rootstock influence on bloom date and fruit maturation of 'Redhaven' peach [Prunus persica (L.) Batsch] was studied over a 3-year period. Rootstock included seedlings (Lovell, Halford, Bailey, and Siberian C) and cuttings (GF677, GF655.2, Damas 1869, and 'Redhaven'). Bloom dates of the various combinations differed in all 3 years, with a range of 3.6, 9.1, and 7.3 days in 1988, 1989, and 1990, respectively. Fruit development period differed each year with a range of 3.9, 5.8, and 4.4 days in 1988,1989 , and 1990 , respectively. 'Weighted-average harvest date also differed with a range of $3.6,2.9$, and 5.6 days in 1988, 1989, and 1990, respectively. 'Redhaven'/Lovell was the latest blooming and maturing combination in all 3 years of the study.
\end{abstract}

Several rootstock have been shown to affect peach bloom date. Okie (1990) reported that trees of 'Sunprince' budded on rooted cuttings of Ta Tao \#24 (PI101686) bloomed later than those on rooted cuttings of either 'Redglobe' or 'Flordaking'. Young and Houser (1980) reported that 'Cresthaven' and 'Harken' budded on Siberian C seedlings bloomed later than those on Lovell or Halford seedlings. Bloom delay can be a useful strategy to escape frost damage.

Reports of rootstock effects on fruit maturation in peach are few. Marangoni et al. (1985) reported no difference in fruit maturity of 'Redhaven' budded on a series of peach seedlings, peach, plum, or hybrid clonal rootstock. Yadava and Doud (1989), however, reported that peach cultivars budded on Lovell seedlings matured later than those on Siberian C seedlings. Additionally, Guerriero et al. (1985) observed that 'Maygrand' fruit matured earlier when budded on P. besseyi (L.H. Bailey) hybrids compared with peach seedling rootstock. The objective of this study was to determine rootstock effects on bloom and fruit maturation of 'Redhaven' peach.

\section{Materials and Methods}

The planting was established in Spring 1984 at the Southeastern Fruit and Tree Nut Research Laboratory, Byron, Ga., and maintained according to guidelines established by the NC140 committee (R.L. Perry, unpublished). 'Redhaven' was budded on seedlings of Lovell, Halford, Bailey, or Siberian C; and clonal rootstock of GF677 (peach $\times$ almond), GF655.2 (plum), Damas 1869 (plum $\times$ plum), or Citation (plum x peach). Ownrooted trees of 'Redhaven' were included as an additional treatment. Soil type was a Faceville fine sandy loam, a clayey, kaolinitic, thermic, Typic Paleudult.

Bloom data were collected as described by Okie (1990) on a series of dates (two to four each year) at 2- to 4-day intervals in 1988, 1989, and 1990 and 50'\% bloom dates (50\% flowers open) determined by interpolation for each plot. Fruit were harvested each year on a series of dates (four to seven each year)

Received for publication 26 July 1991. Accepted for publication 4 Feb. 1992. The cost of publishing this paper was defrayed in part by the payment of page charges. Under postal regulations, this paper therefore must be hereby marked advertisement solely to indicate this fact.

${ }^{1}$ Research Horticulturist.

${ }^{2}$ Associate Professor. at 2- to 4-day intervals at a commercially mature stage, i.e., as ground color changed from green to yellow. Yields are gross totals, since fruit were not sorted for size. Mean fruit weight was determined with a 50-fruit sample from the first harvest date each year. Weighted-average harvest date was calculated with a modification of the procedure described by Stembridge and Gambrell (1974) in that the fraction of fruit gathered on each harvest date was based on fruit weight rather than number of fruit. Fruit development period (FDP) was calculated by subtracting 50\% bloom date from the weighted-average harvest date (after conversion to Julian date) for each plot. Trunk circumference was measured $30 \mathrm{~cm}$ above the soil line following natural defoliation in the fall of each year.

Planting design was a randomized complete block with 10 single-tree replicates of each scion/rootstock combination. Data were analyzed using the general linear model (GLM) procedure of SAS (SAS Institute Inc., 1987). Citation was excluded from analysis because growth was poor and mortality was excessive.

\section{Results and Discussion}

Rootstock influenced bloom date of 'Redhaven' ( $\mathrm{P}<0.0001$ ) each year (Table 1). Years differed $(\mathrm{P}<0.0001)$ even when normalized to the first blooming tree each year (i.e., date of first bloom $=1$; data not shown). This result is probably related to different chilling regimes and bloom-time weather conditions within each year. A rootstock x year interaction $(P<0.0001)$ was also present due to slight differences in relative bloom order each year. 'Redhaven'/LoveU was the latest blooming combination each year, averaging a 3.6-day delay over the next latest combination. 'Redhaven'/GF655.2 and 'Redhaven'/Damas 1869 were the earliest-blooming combinations each year, blooming on average 6.3 days before 'Redhaven'/Lovell over the 3 years. Thus, in some years, use of these two clonal rootstock could increase spring freeze damage to 'Redhaven' compared with 'Redhaven'/Lovell. In contrast, Couvillon (1985) observed no difference in bloom date of 'Redhaven' when budded to seedlings of Lovell, Nemaguard, Halford, or Siberian C, budded to rooted cuttings of 'Redhaven' or GF655.2, or grown as an ownrooted tree.

Differences in bloom date between rootstock treatments suggest differences in the onset of chill-hour accumulation or in chilling requirement of the scion/stock combinations. Observations on fall defoliation were not recorded in 1987 or 1988. 
Table 1. Rootstock influence on bloom date of 'Redhaven' peach, Byron, Ga. (1988-90).

\begin{tabular}{lccc}
\hline \hline & \multicolumn{3}{c}{ Bloom date (Julian) } \\
\cline { 2 - 4 } Rootstock & 1988 & 1989 & 1990 \\
\hline Lovell & $89.8 \mathrm{a}^{z}$ & $87.9 \mathrm{a}$ & $73.0 \mathrm{a}$ \\
Siberian C & $88.0 \mathrm{~b}$ & $83.0 \mathrm{~b}$ & $70.7 \mathrm{~b}$ \\
Halford & $88.1 \mathrm{~b}$ & $82.7 \mathrm{bc}$ & $70.2 \mathrm{~b}$ \\
Redhaven & $88.0 \mathrm{~b}$ & $82.4 \mathrm{bc}$ & $70.2 \mathrm{~b}$ \\
Bailey & $87.7 \mathrm{~b}$ & $82.6 \mathrm{bc}$ & $68.6 \mathrm{c}$ \\
GF677 & $87.9 \mathrm{~b}$ & $81.2 \mathrm{~cd}$ & $67.7 \mathrm{~cd}$ \\
GF655.2 & $86.2 \mathrm{~d}$ & $78.8 \mathrm{e}$ & $66.3 \mathrm{de}$ \\
Damas 1869 & $87.0 \mathrm{c}$ & $80.1 \mathrm{de}$ & $65.7 \mathrm{e}$ \\
MSD & 0.7 & 1.6 & 1.6 \\
Rangew $^{\mathrm{w}}$ (days) & 6 & 11 & 11 \\
Chill hours $^{\mathrm{v}}$ & 1162 & 808 & 1004 \\
\hline ".
\end{tabular}

${ }^{\mathrm{z}}$ Mean separation in each column via Wailer-Duncan k-ratio test $(\mathrm{k}$ ratio $=100)$. Mean of 10 replications.

${ }^{y}$ Rooted cuttings.

${ }^{x}$ Minimum significant difference.

"Across all plots.

"Hours below 7C accumulated through 15 Feb. each year (Weinberger, 1950).

However, in 1989 detailed observations were made, and the date of 50\% defoliation was determined. Fall 1989 defoliation dates correlated positively with Spring 1990 bloom dates $(\mathrm{r}=$ $0.56, P<0.0001$ ). 'Redhaven'/Lovell defoliated last, $\approx 10$ days after 'Redhaven'/Damas 1869, which defoliated first.

Differences in chilling requirement are more easily observed in more southern locations such as ours because our bloom period is expanded. In the southeastern United States, chilling hours accumulate more slowly and are interspersed with periods of warm weather. This situation allows lower-chilling cultivars to commence heat accumulation substantially before higherchilling cultivars, which results in marked differences in bloom date. Total chilling hours were below average in 1990 and even lower in 1989, which further, increased the bloom period expansion. Bloom was slightly advanced in 1989 relative to 1988 despite substantially below-average chilling-hour accumulation (minimally adequate for 'Redhaven', which requires $950 \mathrm{~h}$ ). This response was probably due to higher-than-average temperatures in February and March $(+1.2$ and $+1.5 \mathrm{C}$, respectively). Bloom was markedly advanced in 1990, and temperatures in February and March were considerably higher than average (+3.8 and $+1.5 \mathrm{C}$, respectively). In contrast, chilling hours, bloom dates, and spring temperatures were near normal in 1988.

Covariate analysis of weighted-average harvest date using bloom date, tree size (trunk cross-sectional area), relative growth rate (RGR), and yield efficiency did not significantly improve the GLM fit (data not shown). However, the use of total yield (Table 2) as a covariate with weighted-average harvest date each year substantially increased the $R^{2}$. Weighted-average harvest date of rootstock combinations differed $(P<0.0001)$ over the 3 years (adjusted least-squares means, Table 3 ). The effect of years was significant $(P<0.0001)$. A rootstock $\times$ year interaction was also present ( $P$ c 0.0002). 'Redhaven'/Lovell was the latest-maturing combination in all 3 years, ripening an average of 4.0 days after the earliest combination ('Redhaven' own-rooted).

Rootstock differed $(P<0.0001)$ in their effect on FDP in all 3 years (Table 4$)$. Years differed significantly $(P<0.0001)$, and a rootstock $\mathrm{x}$ year interaction was present $(P<0.0001)$. This interaction appears to be largely the result of variable per-
Table 2. Rootstock influence on total gross yield of 'Redhaven' peach, Byron, Ga. (1988-90).

\begin{tabular}{llcl}
\hline \hline & \multicolumn{3}{c}{ Yield $(\mathrm{kg})$} \\
\cline { 2 - 4 } Rootstock & 1988 & 1989 & 1990 \\
\hline GF677 & $55.2 \mathrm{a}^{\mathrm{z}}$ & $31.2 \mathrm{a}$ & $73.3 \mathrm{a}$ \\
Redhaven & $41.1 \mathrm{~b}$ & $27.5 \mathrm{a}$ & $71.6 \mathrm{a}$ \\
Halford & $43.7 \mathrm{ab}$ & $26.8 \mathrm{ab}$ & $68.0 \mathrm{a}$ \\
Bailey & $36.8 \mathrm{bc}$ & $25.1 \mathrm{ab}$ & $59.8 \mathrm{ab}$ \\
Lovell & $32.8 \mathrm{bc}$ & $4.8 \mathrm{e}$ & $50.9 \mathrm{~b}$ \\
Siberian C & $28.4 \mathrm{~cd}$ & $18.6 \mathrm{bc}$ & $45.6 \mathrm{~b}$ \\
Damas 1869 & $17.3 \mathrm{de}$ & $14.2 \mathrm{~cd}$ & $24.2 \mathrm{c}$ \\
GF655.2 & $12.0 \mathrm{e}$ & $7.7 \mathrm{de}$ & $10.8 \mathrm{c}$ \\
MSD & 11.7 & 8.7 & 15.1 \\
\hline
\end{tabular}

${ }^{2}$ Mean separation in each column via Wailer-Duncan k-ratio test $(\mathrm{k}$ ratio $=100$ ). Mean of 10 replications.

'Rooted cuttings.

${ }^{x}$ Minimum significant difference.

Table 3. Rootstock influence on weighted-average harvest date' (adjusted least-squares means) of 'Redhaven' peach, Byrori, Ga. (198890).

\begin{tabular}{lccc}
\hline \hline & \multicolumn{3}{c}{$\begin{array}{c}\text { Weighted-average harvest date } \\
\text { (Julian date) }\end{array}$} \\
\cline { 2 - 4 } Rootstock & 1988 & 1989 & 1990 \\
\hline Lovell & $183 \mathrm{a}^{\mathrm{y}}$ & $177 \mathrm{a}$ & $168 \mathrm{a}$ \\
Bailey & $180 \mathrm{~b}$ & $175 \mathrm{ab}$ & $164 \mathrm{~b}$ \\
GF677 & $181 \mathrm{ab}$ & $175 \mathrm{~b}$ & $164 \mathrm{~b}$ \\
Siberian C & $179 \mathrm{~b}$ & $175 \mathrm{~b}$ & $164 \mathrm{~b}$ \\
GF655.2 & $180 \mathrm{~b}$ & $174 \mathrm{~b}$ & $163 \mathrm{~b}$ \\
Damas 1869 & $180 \mathrm{~b}$ & $174 \mathrm{~b}$ & $163 \mathrm{~b}$ \\
Halford & $180 \mathrm{~b}$ & $174 \mathrm{~b}$ & $162 \mathrm{~b}$ \\
Redhaven & $179 \mathrm{~b}$ & $174 \mathrm{~b}$ & $162 \mathrm{~b}$ \\
Rangew $^{\mathrm{w}}$ (days) & 9 & 6 & 10 \\
\hline
\end{tabular}

${ }^{\mathrm{z}}$ As described by Stembridge and Gambrell (1974). Means have been converted to Julian date for presentation.

${ }^{y}$ Mean separation in each column of least-squares means (adjusted for covariate, total yield) via pair-wise $t$ tests $(\mathrm{P}<0.0004$ for each individual comparison yields overall $P<0.05$ ). Mean of 10 replications. 'Rooted cuttings.

'Across all plots.

Table 4. Rootstock influence on fruit development period of 'Redhaven' peach, Byron, Ga. (1988-90).

\begin{tabular}{lccc}
\hline \hline & \multicolumn{3}{c}{ Fruit development period (days) } \\
\cline { 2 - 4 } Rootstock & 1988 & 1989 & 1990 \\
\hline GF677 & $94.8 \mathrm{a}^{\mathrm{z}}$ & $94.3 \mathrm{a}$ & $97.0 \mathrm{a}$ \\
Bailey & $92.9 \mathrm{~b}$ & $92.9 \mathrm{ab}$ & $95.9 \mathrm{ab}$ \\
Damas 1869 & $91.9 \mathrm{bc}$ & $93.4 \mathrm{ab}$ & $95.7 \mathrm{ab}$ \\
GF655.2 & $91.9 \mathrm{bc}$ & $94.5 \mathrm{a}$ & $95.3 \mathrm{ab}$ \\
Lovell & $93.1 \mathrm{ab}$ & $87.5 \mathrm{C}$ & $94.9 \mathrm{~b}$ \\
Redhaven $^{y}$ & $91.8 \mathrm{bc}$ & $91.9 \mathrm{~b}$ & $93.0 \mathrm{c}$ \\
Halford & $92.8 \mathrm{~b}$ & $92.1 \mathrm{~b}$ & $92.9 \mathrm{C}$ \\
Siberian C & $91.0 \mathrm{c}$ & $91.5 \mathrm{~b}$ & $92.6 \mathrm{C}$ \\
MSW $^{\text {Range }}$ & 1.8 & 2.1 & 1.8 \\
Rays $^{\text {Vany }}$ & 10.4 & 13.5 & 11.6 \\
\hline
\end{tabular}

${ }^{2}$ Mean separation in each column via Wailer-Duncan $\mathrm{k}$-ratio test $(\mathrm{k}$ ratio $=100$ ). Mean of 10 replications.

${ }^{y}$ Rooted cuttings.

'Minimum significant difference.

"Across all plots.

formance by trees on GF655.2, Damas 1869, and Lovell. GF655.2 and Damas 1869 displayed unusually short fruit development 


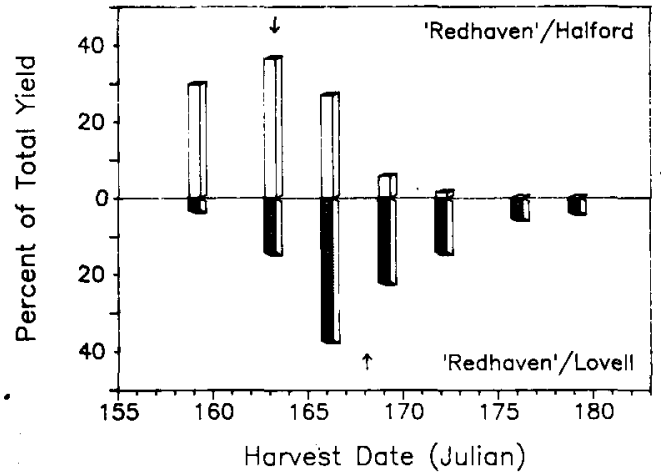

Fig. 1. Percentage of total yield collected each harvest date from 'Redhaven'/Halford and 'Redhaven'/Lovell in 1990 (arrows mark weighted-average harvest date for each combination: 163.1 and 168.0, respectively).

periodsin 1988. In 1989, fruit entrees on GF655.2 were unusually slow to ripen. 'Redhaven'/Lovell displayed an intermediate FDP each year, except in 1989, when its fruit development period was unusually short, possibly the result of an exceptionally low yield (Lovell apparently exacerbated the effects of inadequate chilling). Hence, its delayed harvest date each year is likely the result of its late bloom date.

To illustrate the potential utility of even a small difference in weighted-average harvest date, Fig. 1 shows the percentage of total yield collected on each of seven harvests of 'Redhaven' on Lovell and Halford in 1990. In 1990, trees on Halford bloomed 2.7 days before those on Lovell; however, trees on Halford ripened 4.5 says before those on Lovell. The use or this rootstock effect on fruit maturity could allow more efficient use of limited labor and processing capabilities by spreading harvests over a longer period. Additionally, this effect could allow growers to take advantage of generally higher prices at the start of the season by advancing maturity, or it may be used to fill "gaps" between harvest periods for some cultivars.

\section{Literature Cited}

Couvillon, G.A. 1985. Propagation and performance of inexpensive peach trees from cuttings for high density peach plantings. Acta Hort. 173:271-282.

Guerriero, R., R. Massai, and R. Viti. 1985. Comparison of several Prunus hybrids and peach seedlings used as rootstock for 'Maygrand' nectarine. Acta Hort. 173:251-260.

Marangoni, B., M. Antonelli, D. Scudellari, D. Cobianchi, and A. Liverani. 1985. The behavior of CV. Redhaven on different rootstock. Acta Hort. 173:389-394.

Okie, W.R. 1990. Ta Tao, P.I. 101686, affects bloom date and tree size of 'Sunprince' peach. Fruit Var. J. 44:87-89.

SAS Institute Inc. 1987. SAS/STAT guide for personal computers. Version 6 (cd.). SAS Institute, Inc., Cary, N.C.

Stembridge, G.E. and C.E. Gambrell, Jr. 1974. Measuring peach thinning and maturation responses. HortScience 9:29-30.

Weinberger, J.H. 1950. Chilling requirements of peach varieties. Proc. Amer. Soc. Hort. Sci. 56:122-128.

Yadava, U.L. and S.L. Doud. 1989. Rootstock and scion influence growth, productivity, survival, and short life-related performance of peach trees. J. Amer. Soc. Hort. Sci. 114:875-880.

Young, E. and J. Houser. 1980. Influence of Siberian C rootstock on peach bloom delay, water potential and pollen meiosis. J. Amer. Soc. Hort. Sci. 105:242-245. 